\title{
Merit as Race Talk: The Ontological Myopia of Merit Knowledge
}

Can merit be self-evident and anti-racist within U.S. academic evaluative culture? Race is assumed to be self-evident, and merit is no exception. Merit's reality is not questioned as it is something that is obvious and identifiable within an academic evaluative culture. While scholars note that the definitions of merit reflect the societal elite's cultural norms and definitions of merit transformed to justify racial hierarchies in the U.S., scholars have seldom questioned the racial assumptions upon which these merit transformations take place. Specifically, what have the transformations in merit within the U.S. academy had to presume about race, its role in the social world, and how it operates within the U.S. academy? Conducting a knowledge culture analysis of merit within the academy from 1890 until present, the study argues the contemporary academic evaluative culture has inherited a presumption of the twentieth-century academic evaluative cultures: adjudications of merit are premised upon the colonized proving their assimilability. The colonized have served as fundamental backdrop for how to judge merit because merit in academia's social world emerged as a language and technology to manage the inclusion of racial difference; or simply, merit as race talk. This myopia makes it so academic evaluative cultures do not question whether the study of merit is the same as the colonial study of intelligence. Given this myopia, academia could begin to explore alternative bases of merit knowledge that are not dependent on adjudicating colonized communities' worth.

prabhdeep singh kehal

Brown University

prabhdeep_kehal@brown.edu

Acknowledgements: I thank Laura Garbes, José Itzigsohn, Nabila Islam, Katie Duarte, Nadirah Farah Foley, W. Carson Byrd, and the Race, Indigeneity, and Power Workshop at Brown University for their comments and thoughtful contributions on prior drafts. 
No life is bound up within the period of its conscious existence. No personality dates its origin from its birthday... The materials that go to make the [hu]man, the probabilities of [their] character and activities, the conditions and circumstances of [their] growth... have been accumulating and gathering momentum for generations. - Ann Julia Cooper, What Are We Worth? (1892:164)

In its narcissistic monologue the colonialist bourgeoisie, by way of its academics, had implanted in the minds of the colonized that the essential values - meaning Western values - remain eternal despite all errors attributable to man. - Frantz Fanon, Wretched of the Earth (1963:11)

Can merit be self-evident and anti-racist within the U.S. academic evaluative culture? Race is often assumed to be self-evident (Obasogie 2013), and merit is no exception. Scholars studying changes in admissions policy over higher education's history have argued that the definitions of merit have reflected the societal elite's cultural norms and helped to organize educational systems and justify racial hierarchies in the U.S. at the turn of and throughout the twentieth century (Carson 2006; Wechsler 2014). While these accounts uplift "merit" as a contested concept to define, merit's reality is not in question: merit is something that is obvious and identifiable. As representative of an institution's norms, merit transformed within higher education to became the terrain of contestation for determining who is worthy of inclusion (Karabel 2005; Okechukwu 2019). Thus, in the context of an academic culture, merit is also an inherently political contestation over knowledge production and who is allowed to produce knowledge (Anderson 1993; Bernal and Villalpando 2002; Karabel 2005; Wilder 2013). Though scholars have provided histories on merit's transformations, they have rarely questioned the racial assumptions upon which these transformations take place. Specifically, what have the transformations in merit within the academy ontologically presumed about race and how it operated in the academy?

Conducting a knowledge culture analysis of merit within the academy from 1890 until present, I identify an ontological myopia in academia's evaluative culture through cartographic analysis (kehal, Garbes, and Kennedy 2019; Rodríguez-Muñiz 2015). Ontological myopias are “a particular kind of constriction of the scholarly imagination, rooted in taken-for-granted 
assumptions about the nature and workings of the social world” (Rodríguez-Muñiz, 2015, p. 91). The contemporary academic evaluative culture - which is occupied with defining the appropriate metrics and processes of evaluation for admission, hiring, and promotion within the academy - has inherited an assumption of the twentieth-century academic evaluative culture: adjudications of merit are premised upon the colonized proving their assimilability. The colonized have been the backdrop for how to judge merit because merit in academia's social world emerged as a language and technology to manage the inclusion of racial difference, indicating how relations with the colonized class are part of defining merit. Thus, assumptions about the colonized and how they exist and operate in society are within the realm of ontological exploration (i.e., assumptions of the social world's constitution).

I use cultural sociological tools for studying knowledge production and bring them to bare on historical studies from the sociology of higher education in order to excavate how assumptions about race have sustained transformations of merit knowledge in the academy. I view an academic evaluative culture as a knowledge culture, or a set of implicit epistemological and ontological understandings that "orient, direct, coordinate, explain, and legitimate or justify action" of sociological theorization and analysis (Glaeser 2011:37). A knowledge culture analysis "works to understand how knowledges' symbols, schemas, institutions, and networks shape the terms of social reproduction and transformations" (kehal et al. 2019). To analyze how an academic evaluative culture carries intellectual inheritances, the focus of this analysis is how assumptions that sustained the academic evaluative culture manifested exclusion to maintain white supremacy.1

I start my analysis in the late nineteenth century because higher education historians define this period as when the modern research university emerged (Barrow 1990; Carson 2006; Newfield 2004; Okechukwu 2019; Ross 1991; Soares 2007; Thelin 2004; Veysey 1965; Wechsler 2014). 
For example, John Hopkins University, hailed as the modern research university's originator was founded in 1876, and the Association of American Universities was later founded in 1900, of which Hopkins and 13 other elite, research oriented universities were founding members. I end with contemporary scholarship on merit. The knowledge culture analysis moves across levels of analysis because ontological myopias "are collectively generated and sustained, in part, through cultural understandings and processes" about the social world's composition (Rodríguez-Muñiz 2015:91). U.S. academic evaluative cultures are constructed by scholars both producing scholarship on merit and scholars setting evaluative norms of knowledge within the academy. To attend to these collectively generated and sustained cultures, I analyzed the scholarship of intellectual histories of the academy, colonial and racial histories of education post-Civil War to present, legal scholarship on equal protection and race analysis, and scholarship on merit as it is used within higher education today. Placing these literatures in conversation reveals intellectual linkages between academic valuation and racial ideology.

First, I review the theoretical definitions I use throughout this paper to situate the knowledge culture analysis of merit. Next, my analysis identifies the epistemological shifts concerning definitions of merit taking place within academic evaluative cultures from 1890 until present. By using cartographic analysis from cultural diagnostic approaches, I identify the ontological myopia within this academic evaluative culture. The ontological myopia within academic evaluative cultures makes it so these cultures do not question whether the study of merit is the same as the colonial study of intelligence, overlooking the documented relationships between ideas of intelligence and colonial and racial exploitation (Au 2008; Carson 2006; Grande 2015; Kendi 2017; Privateer 2006). I conclude discussing how existing judicial thought provides one avenue for alternative bases of merit knowledge. 
In treating merit as a cultural object, the knowledge culture analysis highlights contributions for the sociology of knowledge, race, and higher education. First, for the sociology of higher education, I show how merit knowledge's constitution in academia has been linked to colonial understandings of race within the academy's ontological landscape. Second, building on the synergies between the sociology of race and knowledge, the study reveals the ideological processes that naturalize and justify the persistence of colonial racial thought. Finally, in doing so, for the sociology of race, the paper uncovers how racial assumptions guide evaluations, legitimations, and adaptations of knowledge in education, as evaluative cultures can function to determine one's civilizing potential under the veil of educability. Given this myopia, academia could then begin to explore alternative bases of merit knowledge that are not dependent on adjudicating colonized communities' worth.

\section{ARTICULATING COLONIAL RACE, KNOWLEDGE CULTURE, AND METHOD}

In this section, I identify a colonial definition of race used throughout this paper; then, I define a knowledge culture in relation to this definition to frame the subsequent analysis of merit. I conclude discussing the data used for this paper and the method used for coding the literatures.

Under the U.S. history of race, to understand the relationships between education and race, race must be understood as colonial (Grande 2015; Smith, Tuck, and Yang 2018). Race is "an inherited, western, modern-colonial practice of violence, assemblage, superordination, exploitation and segregation" (Hesse 2016:viii). Race as a means to understand relationships over history represents how "colonized populations continue to be racialized in specific ways that mark out and reproduce the unequal relationships into which Europeans have co-opted these populations" (Wolfe 2016:2). To study race in this context is to recognize how higher education 
was connected to the US's ethnic-cleansing projects and how its methods of inclusion/exclusion related with assumptions of racial inferiority that constituted the social world.

I do not aim to essentialize all forms of European colonialism across the globe (DacheGerbino 2017); instead, I focus on settler-colonialism for the U.S. context. In this way, "the colonized" include those individuals whose nations, communities, and subjectivities the U.S. government has historically exploited in its efforts to "transform the new colony into "home"" (Glenn 2015:55). Because settler colonialism's objective is to acquire land and gain control of resources, to do so, the colonizers must eliminate the Indigenous of the land and secure the land for settlers. In the U.S., both these tasks were accomplished by linking Indigenous land dispossession with Black chattel slavery to impose a modernist property regime, which "converted people, ideas, and things into property that could be bought, owned, and sold" (67). Given this backdrop, the colonized should be understood as a description of a class formed due to U.S. colonialism (review Glenn (2015) for a summary of U.S. settler colonialism and racial identity construction domestically); internationally, this includes those who were subject to U.S.'s international imperial expansion.

With these tools, race as a colonial effect of power frames knowledge itself as endowed with assumptions that legitimate the settler position as natural. Race's ontological imprint in education can be traced by assessing an organization's evaluative cultures because a knowledge culture frames "what can be conceived of as 'true-or-false"” (Somers 1996:55) and an educational evaluative culture operates "in a manner that ultimately determines who is 'worthy' of [white] education" (Martinez-Cola 2019:3). A knowledge culture is contingent on the "specific range of thinking, reasoning, and institutional practices possible in a given historical time and space" (Somers 1996:54-55). A knowledge culture is positioned to carry colonial intellectual inheritances 
because, as evaluative cultures, these inheritances imbue the cultures with ideas determining what is considered legitimate and excellent (Glaeser 2011). It is in these cultures that the "scientific cloak of racial knowledge, its formal character and seeming universality, imparts authority and legitimation to it. Its authority is identical with, [the cloak] parasitically maps onto the formal authority of the scientific discipline it mirrors" (Goldberg 2000:154). To understand how racial assumptions construct and legitimate educational knowledge, specific attention is needed on what evaluative cultures reveal about their understandings of race. To track the inheritances is to track how the culture manifested exclusion to maintain white supremacy, and how the current scholarship on merit is implicated.

To conceptualize of a U.S. academic evaluative culture over time, I analyzed scholarship on the histories of U.S. higher education from the 17th century until present; intellectual histories of the U.S. academy in the 19th and 20th centuries; and colonial and racial histories of education and law post-Civil War. From these scholarships, I track how the research university emerged and shifted its purpose and, consequently, evaluative culture. I place these in conversation with contemporary scholarship on merit, higher education, and race to identify inherited assumptions. Then, I draw on the education, psychology, and intelligence scholarships to trace the ontological map upon which these academic evaluative cultures necessarily operate.

To track changes in ideas of race, merit, and higher education, I first reviewed these scholarships to identify significant moments of change relating to race, merit, and higher education from 1611 - when French Jesuits first opened mission schools to educate Indigenous children until 2016 - when the Supreme Court upheld the constitutionality of considering race in admissions (Grande 2015; Reyhner and Eder 2004). This generated an archive of about 500 significant moments that were then shortened to 266 moments that most directly addressed the 
nexus of race, merit, and higher education in the U.S.. I coded these moments into seven broad themes for which they seemed most relevant: race; merit; higher education; race and merit; race and higher education; merit and higher education; and race, merit, and higher education.

Attending to the variation within these seven categories, I generated additional codes for changes in meanings within each category. For example, from the $15_{\text {th }}$ to $19_{\text {th }}$ century, observation was the primary mode for determining scholarly "merit"; these ideas of merit were in flux in the U.S. 19th century as merit moved from ideas of "wealth" and "self-made man" towards "merit as objective" (Daston and Galison 2007; Daston and Lunbeck 2011; Kett 2013). I aggregated my time period into 43 decades and assigned these within-category-themes to a decade. With all subthemes placed in conversation between 1600-2020, I focused on transformations in ideas from when the modern research university emerged around 1890 until present. It is from this qualitative coding I present the following analysis.

\section{THE KNOWLEDGE CULTURE ANALYSIS OF MERIT WITHIN THE ACADEMY}

With these tools and methodology, I offer a knowledge culture analysis of merit within the U.S. academy to identify the epistemological understandings that coordinate and legitimate action within the U.S. academic evaluative culture. First, I provide an analytic periodization: 1890-1960s and 1960s-2010s. Second, I provide a summary of my analysis before each periodization, and then explore the details of the merit transformations. I pay extensive attention to the former period because the educational conflicts and processes initiated in that period established "the basic institutional contours that shape the practical class consciousness of contemporary [U.S.] intellectuals" (Barrow 1990:10). While the former period's epistemological assumptions prompted academics to specify criteria for evaluation, the latter period focused on how to evaluate them.

Colonial Revivalism (1890s-1960s) 
From 1890s-1960s, the colonial revivalism movement (Thelin 2004) brought a remaking of colonial heritage and a centralization of academic and administrative authority (Veysey 1965). While pre-Civil War debates on evaluative cultures had resolved themselves into two camps positive defenses of slavery grounded in history, theology, and economics, and scientific attacks on the humanity of the non-white races (Wilder 2013) - post-Civil War debates had to adapt themselves given Emancipation. Thus, from 1890 to the 1920s, remaking violent colonial histories as positive sources of identity served as a foundation for claiming educational excellence. Throughout these decades, race was a presumed status for exclusion in the social world, but increasing demographic change and the popularity of eugenic thought in the early 1900s demanded a rationale and method for managing the inclusion of racial difference (Carson 2006; Dikötter 1998). To answer questions of academic command and administration and management of racial difference, colonial revivalism provided answers: prioritize exclusivity and selectivity, and mark colonial history as a source of academic prestige. Academics could reminisce of a segregated past because not all forms of racial exclusion were illegal. For example, following the U.S. Supreme Court's upholding of racial apartheid in 1896, in 1908, the Court held that states could prohibit private educational institutions from admitting both Black and white students in Berea College v. Kentucky (i.e., limit desegregation). Thus, using revised colonial histories as sources of academic legitimacy was not inappropriate; it was the brand.

From the 1920s to 1930s, the academic evaluative culture shifted from these questions of administration towards a need for structural conformity. As newer universities attempted to tie their own histories to the U.S.'s colonial origin, structural conformity in operations and productions provided an additional means for claiming excellence. For example, as elite industrialists attempted to influence faculty production, structural conformity in the form of 
governing boards and priorities around efficient production and management set in. Thus, the academic evaluative culture matured its understandings of merit as colonial exclusivity and began developing means to maintain that exclusivity.

Finally, throughout the mid-twentieth century, with the heavy business influence now firmly planted, academic evaluative cultures standardized knowledge production into the role of the expert, and identified academic and racial qualities by which one could be an expert. As desegregation movements took hold in the mid-twentieth century, academic evaluative cultures leading up 1960s had to again address the question of managing racial difference, but now the defined role of the expert could be used in that management. In this way, without having to name the nature of any colonial relationships, implicit assumptions about colonized peoples' place in the social world from the turn of the twentieth century were associated with qualities and methods that placed colonized scholars outside the colonizers' social world by the 1960s.

Repackaging colonial history (1890s-1920s). Colonial revivalism refers to the movement in which "officials at the old colleges, rediscovered and then revitalized their colonial heritage" (Thelin 2004:2). It was most visible in the architecture; buildings on campus, such as residence halls, aided universities in reinforcing the social dynamics and cultural ideas among an elite class of men in a budding new nation (Yanni 2019). Higher education historian John Thelin (2004) noted how Miami University of Ohio redid a prominent campus building as a mixture of 20th century interior and amenities and an exterior replicating the historic College of William and Mary. At William and Mary itself, a nondescript field was replaced with a colonial-style sunken garden to complement its existing colonial style buildings (Thelin 2004). Especially at Brown University and Harvard University, new construction was grounded in a recall of antiquity wherein the appearance was colonial even if amenities were contemporary. This reengagement and 
repackaging of a violent colonial history as a nostalgia of colonialism commemorated a revisionist colonial origin story in the campus's built environment.

With colonial history now evoking nostalgia of a commendable past, colonial revivalism framed one's history as a source of educational excellence for the U.S. public and academics. First, the strongest academic institutional base in academic evaluative culture before and after the Civil War derived its traditions from the cultural, political, and business elites who were in the center and right of the liberal-republican consensus (Ross 1991). This consensus represented political ideologies grounded in racial hierarchies that should be used to organize the social world; while dissent existed in the academy, this consensus held. Thus, as the colonial revivalism movement set in at the turn of the century, prior debates over university purpose and administration shifted towards debates around academic administration, as "factions appeared in response to the tightening executive policies of the institution" (Veysey 1965:vii). Under colonial revivalism, these debates used their colonial histories as sources of "experience" and academic prowess by fostering "standards of academic honor and imitations". For example, at Brown University, history served as evidence of "the durability of an ancient ideas and ideals... that persisted long before the memory of living man" (Thelin 2004:5-6). These ancient ideas and ideals - again within circulation - could be used for justifying racial exclusions while cultivating an exclusive claim to merit grounded in antiquity to be used to judge newer, later institutions.

Transmuting colonial history into academic legitimacy, questions of academic administration included a shift toward selective evaluation practices by the turn of the twentieth century. The University of Michigan first instituted an "active" selective policy in which colleges did not wait for students to present themselves for faculty evaluation, rather, faculty members "inspected feeder high schools and waived entrance examinations for graduates of schools that 
passed muster" (Wechsler 2014:xi). Though it was likely not intended, this form of active admissions set a precedent for universities to select who should play a societal leadership role. For example, in this shift towards selective practices, academic prestige was measured by exclusivity, or the ability to reject based on social and academic criteria; as fears of being "overrun" by students who were poor, female, Jewish, and/or Black, the ability to limit these constituencies' inclusion was needed (Karabel 2005; Wechsler 2014). Thus by the 1920s, racial identities "became determinants of admission and rejection at many colleges - coeducational and single-sexnominally open to academically qualified students" (Wechsler 2014:ix). These shifts in administrative focus and exclusivity were no shock in academic circles; it was the expected result of a maturing organization "too powerful and complex to be explained by the several ideas which had sought to preside over its founding" (Veysey 1965:259). Though historians do not suggest a singular, unified philosophy for higher education during this maturation, the centralization of academic authority and prestige-as-exclusivity brought pressure to emerging universities that wished to access academic prestige but did not have a repackaged colonial history to use.

Structural conformity (1920s-1930s). A major factor contributing to the emergence of higher education institutions was a growing transactional relationship between industry and academia (Newfield 2004). As the research university form matured by the 1920s, administrative authorities began centralizing into governing boards and presidents who were attuned to the demands of the industrial elite, while academic authority centralized into faculty research due to these demands. For example, the new industrial elite's economic and political rise was brought about through U.S. corporations' and enterprises' discretionary wealth produced in the late nineteenth century (Barrow 1990; Thelin 2004). Yet, the cost of standardization can often be agency; higher education historian Laurence Veysey described this centralization of the academic 
enterprise as the academic establishment's loss of freedom. Namely, to "succeed in building a major university, one now had to conform to the standard structural pattern in all basic respects no matter how one might trumpet one's few peculiar embellishments. A competitive market for money, students, faculty, and prestige dictated the avoidance of pronounced eccentricities" (Veysey 1965:340). Thus, new institutions that had no repackaged colonial history from which to claim excellence could now name structural similarities between themselves and the historic colleges, such as academic standards and operations, as evidence of prestige and legitimacy (Kett 2013).

Conformity to this structural pattern came in the form of academic standards, and manifested in the determination of what faculty are to produce. Political scientist Clyde W. Barrow (1990) documents how faculty specialization was tied to industry demands for management of output. Morris L. Cooke, a colleague of Frederick Taylor - known as the father of scientific management - led a Carnegie Foundation sponsored study on making universities more efficient. In the report, Academic and Industrial Efficiency, Cooke aimed to make "an estimate of the cost and the output both in teaching and research" in order to measure educational institutions' efficiency and productivity through a similar method to managing industrial factors (Barrow 1990:67). Cooke recommended that promoting intensive mass production would require greater faculty research and teaching specialization, and standardization would facilitate this mass production (Barrow 1990). The Carnegie Foundation even introduced short-lived pensions for faculty to incentivize faculty behaviors, and worked with the Rockefeller Foundation's General Education Board and United States Bureau of Education to rationalize higher education into effective systems (Thelin 2004; Veysey 1965). By the 1930s, institutions had widely implemented Carnegie's standards, adopted the corporate model for universities, and had their academic boards 
and university presidencies composed of corporate executives and lawyers and bankers (Gonzales 2018; Thelin 2004). Institutions that did not meet these standards could then be considered not of high quality and recommended for closure due to the standards; for example, historically Black colleges and universities, institutions for educating Black youth, were targeted (Anderson 1988).

As industry oriented faculty worth towards the production of research and specialization, standardization practices coalesced into the idea of "academic professionalism", which provided formal gradations of rank and promotion for faculty. Though this professionalism aided in the construction of and the legitimacy of the academic as a professional, standardization innovations were aimed at recuperating losses from depreciated capital, of which now faculty were a primary source (Barrow 1990; Newfield 2004; Thelin 2004). Thus, merit remained a concept for maintaining exclusivity and production, but now included methods and criteria for assessing professionalism as part of merit for faculty. Yet, under colonial revivalism, academic standards and professionalism were based in the cultural, political, and business elites who were in the center and right of the liberal-republican consensus. Thus, ratings, rankings, and reputation became sources of pride and tools of coercion and coordination (Thelin 2004). As universities were pressured for structural conformity to be academically prestigious and legitimate, faculty were pressured to produce research under a corporate model.

The expert: Standardizations of knowledge production (1940s-1960s). Yet, if the faculty role is defined in terms of capital and faculty production is manageable via ratings, rankings, and reputation, can anyone be faculty in twentieth century U.S.? The academic evaluative culture during the mid-twentieth century continued efforts towards standardization of knowledge production, solidifying the role of "the expert". In this calculus though, elite industrialists held sway. With the faculty role defined in relation to ensuring a return on investment, "the role of the 
expert meant that once educational questions were reformulated as problems of business organization and the investment of public capital, then presumably experienced business- men... could rightly claim to be the experts" (Barrow 1990:97). By defining the faculty role via the commodification of their labor, exclusivity remained fundamental to being an expert because an expert was either a trained member of the faculty (via navigating the academy) or an experienced business person (via succeeding in the marketplace) - never educators, farmers, workers, students, or the general public (Barrow 1990; Du Bois 1973).

Given the selection methods that had emerged between by the 1920s for undergraduate admission, underlying these practices of incremental management among the faculty were logics of racial exclusion. With administrators and investors defining the faculty role within the research university's confines, questions of faculty capabilities and qualities required attention. Control over who would educate the next generation's leaders was of parallel, fundamental concern (Anderson 1993). To do so, administrators and faculty used their impersonal, mechanical selective mechanism for determining who was educatable (i.e., undergraduates) (Porter 1995; Wechsler 2014), while relying on their norms of prestige to limit who could be faculty (i.e., experts). Under this scheme, any exclusionary decisions were the result of the algorithm; merit was self-evident via mechanical objectivity and racial exclusion was, therefore, a legitimate byproduct.

For example, in the first, documented systematic attempts to racially diversify the professoriate, the relationship between faculty, merit, and race becomes explicit. Until 1941, no Black scholar had been hired as permanent faculty at a predominantly white US institution (Anderson 1993; Slater 1998). With the influx of students into higher education after World War II and colleges beginning to place limits on enrollment, higher education was confronting a faculty shortage. Fred G. Wale spearheaded a nationwide campaign introducing Black scholars to over 
400 northern white universities presidents (Anderson 1993). While only a handful were hired, the presidents' responses reveal assumptions about where colonized scholars fit into the academic evaluative culture's social world . I quote at length:

Meritocracy became the fragile bridge across the intolerable contradictions between equality and racism. Indeed, the presidents of northern white universities resorted to meritocratic principles as their most ardent defense of traditional racial and ethnic discrimination. In this marriage between racism and meritocracy, nonracist rationales meant not only a defense of the traditional exclusion of African American scholars from northern white universities, they defined that tradition of exclusion as the consequence of fair and equitable principles and procedures... Instead of viewing racial and ethnic exclusion as the antithesis of merit, the presidents found a way out of this uncomfortable confrontation by constructing a set of rationales that effectively defined African American scholars as the antithesis of merit. To be sure, their definitions of merit extended beyond strict academic achievement. They included 'institutional needs,' 'geography,' 'population,' and 'local community attitudes,' and other criteria that were used to justify the exclusion of African American scholars on 'merit' grounds. Thus, they could hold on to their faith in meritocracy while excluding African American scholars from faculty positions in their institutions (Anderson 1993:174, emphasis my own)

When Wale reached out to white university presidents during their faculty shortage, white presidents argued that any intentional efforts to give Black scholars attention could be unfair treatment of white scholars. In doing so, presidents explicitly named white victimhood as a site of protection from Black and other colonized communities, showing how relations with the colonized class are part of defining merit. Merit, in this formulation, deems what types of knowledge are worthy of acclaim and justifies the exclusion of colonized scholars, in particular Black scholars (Prescod-Weinstein 2020).

By the 1950s, desegregation legal victories challenged the academic evaluative culture on how to include those who had been explicitly excluded for centuries. Leading up to the 1960s, desegregation intensified, with Brown v Board decided in 1954, and subsequent Brown decisions in 1955 and 1978. This meant that the 20th century paranoia that arose due to post-Emancipation and immigration was reinvigorated again in the 1960s, now contending with a different playing 
field of inclusion and exclusion. While the modern research university form bloomed across the U.S., no changes in academic or administrative control in selection processes displaced the sons of prestigious institutions' clients (Kett 2013). Rather, because standards had not initiated the existing demographic exclusions at the start of the twentieth century, evaluative cultures inherited these exclusions (Carson 2006). Now, standards could be a means to manage racial difference in the face of immense demographic and societal change experienced after the Civil Rights Movement (Hartman 2019).

\section{Civil Rights and Multicultural Inclusion}

From the 1960s until present, the academic evaluative culture transformed to dictate the terms of how to evaluate since what to evaluate had not been fundamentally challenged. For example, between 1951 and 1971, elite academics minimized their use of moral and social background criteria for defining merit, while the use of intellectual and technical criteria increased; despite these changes, the use of personal criteria remained the same (Tsay et al. 2003). With the civil rights movement questioning the positive role of history, judicial decisions played a structuring role in this shift of evaluation. In particular, conservative and right-wing activists' legal challenges appropriated civil rights tactics, placing the question of merit and race in the courts with the hope of dismantling civil rights gains (Okechukwu 2019). As a result, the academic evaluative culture from 1990s-2010s considered how to be judicially compliant with the explicit exclusions they made. Though multicultural inclusion efforts invited racial integration, merit continued to operate as a way for the colonizers' imagined social world to persist, as colonized scholars could legitimately be excluded from prestigious institutions with a judicial rationale.

From desegregation to desegregation abandoned (1960s-2010s). Desegregation movements from the mid-twentieth century had found partial success in ending segregation's 
legality but that did not end segregation. In fact, since 1960, trends have reversed and racial resegregation has emerged at all levels of education (Fiel and Zhang 2019; Hinrichs 2015; Teddlie and Freeman 2002). Inheriting the impersonal selection method for mechanically objective evaluation in primarily undergraduate, but also graduate, admissions (Porter 1995; Wechsler 2014), the sociology of merit focused on the legal question of how to consider race throughout the 1970s. In 1978 with the U.S. Supreme Court case of Regents of the University of California v. Bakke, the entire academic enterprise was prompted to reconsider how race could be tied to educational efforts. Under this model, race was a suspect category because it had created societal harm and justification was needed for its reparative consideration in evaluation. Within this calculus, race had been used to harm, and continuing its use could perpetuate that harm.

In the 1980s, desegregation brought further academic and policy attention to the legal relationships between race and education. These efforts generated the critical legal studies and other intellectual traditions, which not only challenged the prevalent academic evaluative culture, but also most directly addressed the relationships between intelligence, merit, and race (Crenshaw 2011; Crenshaw et al. 2019). These academics named and explained how disciplinary knowledge is "more than the sum of separate inquiries in discrete areas of knowledge. It is part of a historically specific body of knowledge, an episteme, that contains premises, presumptions, and practices that work together to hide the workings of racialized power" (Crenshaw et al. 2019:11). Yet, despite their efforts, these academic - who were among the first cohorts of scholars from colonized communities to enter the professoriate in the 1970s and 1980s - confronted an academic evaluative culture that had inherited its assumptions about colonized communities; these contributions were consequently marginalized (Ferguson 2012). 
The judicial focus on how race, education, and merit operated in tandem throughout the turn of the twenty-first century (1990s-2010s) brought scholarly focus on higher education's bureaucracy. In particular, the academy reconsidered its evaluative process for admissions, hiring, and promotion by focusing on determining the best mixture of criteria to consider for evaluation (Bastedo et al. 2018; Nettles 2019). These approaches, continuing some of the work of desegregation, channel critiques of the process into research on counteracting implicit and explicit bias towards historically minoritized identities (Martin and Phillips 2019; Rivera 2017; Thorngate, Dawes, and Foddy 2008).

Alongside these efforts, historical analyses conducted at the turn of the twenty-first century have attempted to map out higher education's racial politics . Scholarship has aimed to understand the causes of desegregation in higher education (Stulberg and Chen 2014), the motivations behind desegregation (Skrentny 1996), the dilution of desegregation efforts (Berrey 2019), and the "politics" of merit (Karabel 2005; Warikoo 2016). These historical studies on merit framed the admissions processes as a "negotiated settlement among contending groups, each wishing to shape admissions criteria and the actual selection process to produce the outcome they prefer" (Karabel 2005:6). Rather than assigning particular partisan or political intent to decisions, this tradition indicts higher education institutions for arguing that academic evaluative processes resemble objective review (Au 2008; Fass 1980; Littler 2017; Probolus 2018; Stevens 2007). Merit, then, is a concept that is open for interpretation, and evaluative processes of merit should be crafted towards aligning the evaluation process with the stated outcome.

\section{CULTURAL DIAGNOSTICS}

Cartographic Analysis: Merit Knowledge as "Race Talk" 
It is within the above history that the present academic evaluative culture understands merit as constructed and political. In this section, I use cartographic analysis, one operation of cultural diagnostics, to reveal the ontological myopia within this academic evaluative culture of merit. Cartographic analysis reconstructs the field's ontological landscape; the task is to trace the assumptions and claims made about relevant social dynamics and themes within the analyzed academic evaluative culture, and how those presumptions apply to colonized community through merit. First, I discuss how this academic evaluative culture's imagined social world relies on intelligence to claim merit as self-evident (Porter 2019); then, I detail how the accompanied intelligence testing methods were foundational for education's role in ranking and managing racial difference for higher education. Finally, I elaborate on the notion of merit as race talk. Within the social landscape identified through cartographic analysis, merit became the language by which individuals from colonized communities are evaluated for how well they conform to the academic evaluative culture; put simply, merit as race talk. Thus, assumptions about the colonized and their role in society are the basis upon which to judge merit. Within the framing of race as colonial, adjudications of merit are, therefore, premised upon the colonized proving their assimilability into colonial educational projects. While colonial revivalism provided an ideological structure for interpreting and using colonial history to articulate values of exclusivity and prestige, civil rights and multicultural inclusion did not change this structure.

\section{Intelligence and Its Imagined Social World}

Attempts to identify and assess intelligence became national priorities at the turn of the twentieth century, and intensified in the interwar years (Carson 2006); though new tests from the mid-twentieth century had dropped the term "IQ" to distance themselves from controversies over eugenics, "these post-WWII standardized tests were IQ tests in all but name" (Porter 2019:3). 
From 1890 until then end of the 1940s, discourses on intelligence explicitly defined the social world for society, placing questions of educability as questions of ability/disability and eugenics (Carson 2006). In particular, mental testing "as a measuring device was a defining and sorting instrument, a way of distinguishing and differentiating which, given the cultural concerns of the time and the context of the growing use of statistical techniques like normal distributions, correlations, mean and factor analysis, led predictably to racial comparisons" (Fass 1980:439). From the 1940s onwards, mental testing became the most popular psychometric method for determining and judging intelligence capacities in education, but under the framing of standardized testing (Fass 1980; Lemann 1999; Petrina 2001). While mental testing could have served as a diagnostic tool within the confines of a colonial institution for potentially ameliorating the historical harms of colonialism, it did not. Instead, the IQ and other mental tests provided racism with scientific precision, and "an absolute calibration and a ranked hierarchy as demonstrated by performance differences on tests" (Fass 1980:444). Thus, whereas 19th century evolutionary science provided the assumption that some races were intellectually superior to others, psychometrics provided a scholarly justification to support this colonial belief, extend to other populations, and enable its perpetuation (Porter 2019).

Given the demographic and social change taking place over the start of the twentieth century (Hartman 2019), intelligence had two paths for development. On one hand, intelligence could have been understood "as dynamic systems of social transaction resulting in different kinds of knowledge making - specific to task, discipline, and learning context - to which different individuals enjoyed, were allowed, or sought out different kinds and degrees of access" (Porter 2019:24). Instead, intelligence took a second path: an individualized epistemology, restabilizing and relocalizing intelligence as "an inherent and differential property of selves" and "as a 
measurable fixed personal essence" (Porter 2019:25). As such, with intelligence identified as a real thing to understand via a method tending "toward hereditarianism, and its eugenical concerns about 'subnormality,' 'degeneration,' immigration and national intelligence," everyone now had some intelligence: intelligence was self-evident and measurable (Porter 2019:4).

As a result of focusing on testing of intelligence as the appropriate method for evaluating individual merit in education, the universalization of every student "having merit" was inserted into educational practice. Yet, this was done during the popularity of the eugenics movement (Dikötter 1998). Because mental testing emerged as an explicit way to order and rank individuals expressly under the assumptions of colonized communities being intellectually inferior, evaluations of merit within the academy necessarily placed white individual's testing abilities and results as the norm. As institutions shifted from using racial identity as the criteria for exclusion to using it for inclusion after the civil rights movement (Stulberg and Chen 2011, 2014), merit as the concept for inclusion served the role of assessing how well an individual from the colonized class could assimilate within the colonizer's culture if given equal opportunity to change. Within this framework, the colonized remained excluded from the category of natural and civilized (Jung 2019) unless they assimilated with the colonizer's norms to become civilized or become extinct (Fanon 2005; Seamster and Ray 2018).

Though the association of eugenics with mental testing prompted a change in framing (Lemann 1999; Porter 2019), this social world view of intelligence throughout the twentieth century coincided with the faculty's worldviews. Faculty within the academic evaluative culture at the start of the 1900s had the desire to not only identify "a natural scientific path" but also define the social-historical world as subject to this natural process (McKee 1993; Ross 1991:xiv). These were not trivial or arbitrary assumptions about mental inferiority among the colonized class. In 
fact, faculty's understandings of racial inferiority were funneled and reinforced through a pipeline from secondary education into higher education. Within the educational field, questions of intelligence in the U.S. were questions of ability/disability among the colonized class. Primary and secondary education schools adopted mental testing as a way to organize their students and teaching, presuming some would be educatable while others were not worthy for higher education (Porter 1995, 2019). Higher education institutions relied on these schools' evaluations to determine acceptable students from which to recruit undergraduates (Wechsler 2014). Thus, through the use of mental testing throughout secondary and higher education, racial exclusion was a by-product "of a whole manner of thinking, of perceiving, and of ordering" - in other words, of the academic evaluative culture (Fass 1980:445).

By making intelligence an individual property of every person, everyone had intelligence and education institutions were tasked with assessing this intelligence to sort students accordingly. Despite the desegregation and civil rights movements' victories in the mid-twentieth century to make separate but equal exclusion on the basis of race unconstitutional, this resulted in a change of method in assessing race, not inherently a change in racial ideology (Bridges 2015; Joshi 2019). Later, multiculturalism invited visual integration, but not a dismantling of colonial thought. Ideologically, through intelligence as individual, intelligence could "overlap, substitute, and perform ideological labor in place of race in this post-Brown versus Board moment and in these particular educational contexts" (Porter 2019:24). This conceptual and cultural conflation transmuted early twentieth century eugenic-based notions and methods of intelligence into appropriate twenty-first century notions and methods for assessing merit in the academy.

In fact, the academic evaluative culture was well positioned to carry forth the same racial ideology under different methods after the challenges to affirmative action began in the 1970s 
(Gotanda 1991). By the 1980s, federal desegregation of higher education had been all but fully abandoned and the radical movements of the 1970s had been appropriated within the academic enterprise (Ferguson 2003, 2012; Shaw 2016). As the racial ideology persisted, gaining increased challenges at the turn of the twenty-first century (Crenshaw 2011), the ontological myopia - of merit being the site of adjudicating the colonized class's assimilability - persisted within the academic evaluative culture. Thus, the contemporary academic evaluative culture does not question whether the study of merit is not the same as the colonial study of intelligence (Carson 2006; Grande 2015; Hesse 2016; Privateer 2006). Within this social landscape, merit is the language by which individuals from colonized communities are evaluated for how well they conform to the academic evaluative culture. Merit is race talk.

\section{Merit as race talk}

The identified ontological myopia - adjudications of merit are premised upon the colonized proving their assimilability - means that the ideas that define how one is "meritorious" for inclusion have been defined in relation to how well colonized populations are assimilating. Social scientists in the $19_{\text {th }}$ and 20th century saw the world changing but recreating itself in its United States form; those who are more organizationally efficient to assimilate amidst this changing world are meritorious, while those who are more difficult to assimilate are deemed unqualified or unmeritorious. This is not to suggest that individuals who are from colonized communities and who are deemed to be meritorious are assimilated (la paperson 2017). Rather, the myopia suggests that the institution deems individuals deserving for its purposes in spite of their colonized status; assimilation is a process of subject creation.

To theorize of merit as race talk, it is fruitful to review what I mean by assimilation in the U.S. educational context. Racial progress narratives have "[teleological] assumptions about linear 
progress [that] impose a false logic on history and visions of the future" while using this logic to "retroactively [explain] history as a series of necessary steps to arrive at the present" (Seamster and Ray 2018:317). As colonized communities had to increasingly be included throughout the twentieth century, the academic evaluative culture had to narrate this inclusion towards an end. Under this narrative, scholars presumed three potential outcomes would emerge for (formerly) colonized communities: assimilation, extinction, and regression. Scholars who imagined extinction "foresaw racial conflict that would lead to one group's eradication," wherein extinction could be managed through extreme social control; those who foresaw regression believed "that 'inferior' races were incapable of civilization and, at worst, would erode white superiority" (Seamster and Ray 2018:317). The academic evaluative culture effectively chose assimilation as its goal, as separate but equal in education was no longer constitutional, and because some scholars thought miscegenation and adoption of "mainstream culture" would result in these communities assimilating (and disappearing) (Seamster and Ray 2018). Thus, merit as race talk provided a language and technology by which the desired outcome within the academic evaluative culture could be knowledge, but knowledge producers had to assimilate as faculty experts through the academy to be legitimate.

In the context of a settler society like the U.S., underwriting these processes is the ontological presumption that the settler position is the position of knowledge authority; if change is going to happen within a settler university, it happens with and prioritizing the settlers' consent. For example, as the U.S. university system emerged at the turn of the twentieth century, "instead of the university growing down and seeking to comprehend in its curriculum the life and experience, the thought and expression of lower classes, it almost invariably tended to grow up and narrow itself to a sublimated élite of mankind" (Du Bois 1973:85-86). While emancipated 
Black communities looked towards education as a means for social uplift after the Reconstruction era, they confronted a tiered educational system in which there was schooling either for democratic citizenship or second-class citizenship (Anderson 1988; Du Bois 1973). For Indigenous youth, even though boarding schools began closing after 1928, it was not until 1970s that parents were granted the legal right to stop their child's placement in off-reservation schools (Northern Plains Reservation Aid 2015). As a result, Indigenous communities in U.S. higher education remains rarely acknowledged (Tachine, Cabrera, and Bird 2017; Waterman 2019). In this system, merit in

education was defined by whether students conformed with the larger political social system in which Black and Indigenous communities were educated for the purposes of continued assimilation, or extinction.

\section{CONCLUSION}

Can merit be self-evident and anti-racist within U.S. academic evaluative cultures? This knowledge culture analysis of merit within the academy highlights how assumptions about colonized communities and their roles in society were the backdrop for transformations in merit. By analyzing merit reflexively, the ideological linkages between intelligence and evaluations of merit in the academy take on a different light: evaluations of merit emerged as colonial institutions navigated a changing society in which their constitutive criteria for inclusion and exclusion were under attack. Intelligence provided an ideology and method for managing the ontological change in a settler society. Thus, while faculty may be valuable capital due to the research they produce, the teaching they perform, and the training they receive to become experts, this academic social world begins from a presumption of the colonizers as intelligent and the colonized as potentially having sufficient intelligence. Under this analysis, merit cannot be self-evident and anti-racist; 
instead, alternative bases of merit knowledge are needed that do not adjudicate the colonized class's worth, or merit, under the veil of educability.

As alternative foundations for merit knowledge production are pursued, Justice Harry Blackmun's 1978 concurring opinion in the Regents of the University of California v. Bakke exhibits a constitutional basis for one. What is required is recognition of race's function for racial supremacy in the U.S.: "to get beyond racism, we must first take account of race. There is no other way. And in order to treat some persons equally, we must treat them differently. We cannot - we dare not - let the Equal Protection Clause perpetuate racial supremacy." Justice Sonia Sotomayor's 2014 dissent in Schuette v. Coalition to Defend Affirmative Action once again raised this framing with a focus on how racism is historical and tied to racial supremacy: "The way to stop discrimination on the basis of race is to speak openly and candidly on the subject of race, and to apply the Constitution with eyes open to the unfortunate effects of centuries of racial discrimination." Though Blackmun does not name white or settler supremacy and though Sotomayor frames management of colonized communities as discrimination, the Justices provide a constitutional basis for considering race that challenges assumptions that colonized communities are deficient. Thus far, merit knowledge has been constricted by an ontological myopia that marks colonized communities for assimilation or extinction; to construct alternative bases of merit knowledge, the myopia must, first, be acknowledged and rejected. 
Notes

1. White supremacy is "a political, economic, and cultural system in which whites

overwhelmingly control power and material resources, conscious and unconscious ideas of white superiority and entitlement are widespread, and relations of white dominance and non-white subordination are daily reenacted across a broad array of institutions and social settings" (Ansley 1989:1024). 
Anderson, James D. 1988. The Education of Blacks in the South, 1860-1935. Chapel Hill, NC: University of North Carolina Press.

Anderson, James D. 1993. "Race, Meritocracy, and the American Academy during the Immediate Post-World War II Era." History of Education Quarterly 33(2):151-75.

Ansley, Frances L. 1989. "Stirring the Ashes: Race, Class and the Future of Civil Rights Scholarship." Cornell Law Review 74(6):993-1077.

Au, Wayne. 2008. Unequal By Design. 1 edition. New York, NY: Routledge.

Barrow, Clyde W. 1990. Universities and the Capitalist State: Corporate Liberalism and the Reconstruction of American Higher Education, 1894-1928. Madison, WI: University of Wisconsin Press.

Bastedo, Michael N., Nicholas A. Bowman, Kristen M. Glasener, and Jandi L. Kelly. 2018. "What Are We Talking About When We Talk About Holistic Review? Selective College Admissions and Its Effects on Low-SES Students." The Journal of Higher Education 89(5):782-805.

Bernal, Dolores Delgado and Octavio Villalpando. 2002. "An Apartheid of Knowledge in Academia: The Struggle Over the 'Legitimate' Knowledge of Faculty of Color." Equity \& Excellence in Education 35(2):169-80.

Berrey, Ellen. 2019. "Is Diversity Racial Justice? Affirmative Action in Admissions and the Promises and Perils of Law." in Challenging the Status Quo: Diversity, Democracy, and Equality in the 21st Century, edited by S. Collins, D. G. Embrick, and M. Dodson. Chicago, IL: Haymarket Books.

Bridges, Khiara M. 2015. "Race Matters: Why Justice Thomas and Justice Scalia (and the Rest of the Bench) Believe That Affirmative Action Is Constitutional." Southern California Interdisciplinary Law Journal 24(607):50.

Carson, John. 2006. The Measure of Merit: Talents, Intelligence, and Inequality in the French and American Republics, 1750-1940. Princeton, New Jersey: Princeton University Press.

Crenshaw, Kimberlé Williams. 2011. “Twenty Years of Critical Race Theory: Looking Back To Move Forward." Connecticut Law Review 43(5):100.

Crenshaw, Kimberlé Williams, Luke Charles Harris, Daniel Martinez HoSang, and George Lipsitz, eds. 2019. Seeing Race Again. Berkeley, CA: University of California Press.

Dache-Gerbino, Amalia. 2017. "Mapping the Postcolonial Across Urban and Suburban College Access Geographies." Equity \& Excellence in Education 50(4):368-86.

Daston, Lorraine and Peter Galison. 2007. Objectivity. Zone Books. 
Daston, Lorraine and Elizabeth Lunbeck. 2011. Histories of Scientific Observation. Chicago, IL: University of Chicago Press.

Dikötter, Frank. 1998. "Race Culture: Recent Perspectives on the History of Eugenics." The American Historical Review 103(2):467-78.

Du Bois, W. E. B. 1973. The Education of Black People: Ten Critiques, 1906 - 1960. edited by H. Aptheker. New York, NY: Monthly Review Press.

Fanon, Frantz. 2005. The Wretched of the Earth. New York, NY: Grove Press.

Fass, Paula S. 1980. "The IQ: A Cultural and Historical Framework.” American Journal of Education 88(4):431-58.

Ferguson, Roderick A. 2003. Aberrations In Black: Toward A Queer Of Color Critique. Minneapolis, MN: University of Minnesota Press.

Ferguson, Roderick A. 2012. The Reorder of Things: The University and Its Pedagogies of Minority Difference. 1 edition. Minneapolis: University of Minnesota Press.

Fiel, Jeremy E. and Yongjun Zhang. 2019. "With All Deliberate Speed: The Reversal of CourtOrdered School Desegregation, 1970-2013.” American Journal of Sociology 124(6):1685-1719.

Glaeser, Andreas. 2011. Political Epistemics: The Secret Police, the Opposition, and the End of East German Socialism. Chicago, IL: University of Chicago Press.

Glenn, Evelyn Nakano. 2015. "Settler Colonialism as Structure: A Framework for Comparative Studies of U.S. Race and Gender Formation." Sociology of Race and Ethnicity 1(1):5272.

Gonzales, Leslie D. 2018. "Subverting and Minding Boundaries: The Intellectual Work of Women." The Journal of Higher Education 89(5):677-701.

Gotanda, Neil. 1991. "A Critique of 'Our Constitution Is Color-Blind."” Stanford Law Review 44(1):1-68.

Grande, Sandy. 2015. Red Pedagogy: Native American Social and Political Thought. 10th Anniversary Edition. Lanham, Md: Rowman \& Littlefield Publishers.

Hartman, Saidiya. 2019. Wayward Lives, Beautiful Experiments: Intimate Histories of Social Upheaval. New York, NY: W. W. Norton \& Company.

Hesse, Barnor. 2016. "Preface: Counter-Racial Formation Theory." in Conceptual aphasia in black: displacing racial formation, Critical Africana studies, edited by P. K. Saucier and T. P. Woods. Lanham: Lexington Books. 
Hinrichs, Peter. 2015. An Empirical Analysis of Racial Segregation in Higher Education. 21831. National Bureau of Economic Research, Inc.

Joshi, Yuvraj. 2019. "Racial Indirection.” UC Davis Law Review 52(5).

Jung, Moon-Kie. 2019. “The Enslaved, the Worker, and Du Bois's Black Reconstruction: Toward an Underdiscipline of Antisociology." Sociology of Race and Ethnicity 5(2):15768.

Karabel, Jerome. 2005. The Chosen: The Hidden History of Admission and Exclusion at Harvard, Yale, and Princeton. Boston, MA: Houghton Mifflin Company.

kehal, prabhdeep singh, Laura Garbes, and Michael D. Kennedy. 2019. "Critical Sociology of Knowledge." in Oxford Bibliographies in Sociology, edited by L. Spillman. New York, NY: Oxford University Press.

Kendi, Ibram X. 2017. Stamped from the Beginning: The Definitive History of Racist Ideas in America. Bold Type Books.

Kett, Joseph F. 2013. Merit : The History of a Founding Ideal from the American Revolution to the Twenty-First Century. Ithaca, NY: Cornell University Press.

la paperson. 2017. A Third University Is Possible. Minneapolis, MN: University of Minnesota Press.

Lemann, N. 1999. The Big Test: The Secret History of the American Meritocracy. New York, NY: Farrar, Straus and Giroux.

Littler, Jo. 2017. Against Meritocracy: Culture, Power and Myths of Mobility. New York, NY: Routledge.

Martin, Ashley E. and Katherine W. Phillips. 2019. "Blind to Bias: The Benefits of GenderBlindness for STEM Stereotyping.” Journal of Experimental Social Psychology.

Martinez-Cola, Marisela. 2019. "Visibly Invisible: TribalCrit and Native American Segregated Schooling.” Sociology of Race and Ethnicity 2332649219884087.

McKee, James B. 1993. Sociology and the Race Problem: The Failure of a Perspective. Champaign, IL: University of Illinois Press.

Nettles, Michael T. 2019. "History of Testing in the United States: Higher Education." The ANNALS of the American Academy of Political and Social Science 683(1):38-55.

Newfield, Christopher. 2004. Ivy and Industry: Business and the Making of the American University, 1880-1980. Durham, NC: Duke University Press.

Northern Plains Reservation Aid. 2015. "Native American History and Culture: Boarding Schools." Northern Plains Reservation Aid. Retrieved 
(http://www.nativepartnership.org/site/PageServer?pagename=airc_hist_boardingschools ) .

Obasogie, Osagie K. 2013. Blinded by Sight: Seeing Race Through the Eyes of the Blind. Palo Alto, CA: Stanford University Press.

Okechukwu, Amaka. 2019. To Fulfill These Rights: Political Struggle Over Affirmative Action and Open Admissions. New York: Columbia University Press.

Petrina, Stephen. 2001. “The 'Never-to-Be-Forgotten Investigation': Luella W Cole, Sidney L Pressey, and Mental Surveying in Indiana, 1917-1921.” History of Psychology 4(3):24571.

Porter, Jim Wynter. 2019. "Guidance Counseling in the Mid-Twentieth Century United States: Measurement, Grouping, and the Making of the Intelligent Self." History of Science 0073275319874977.

Porter, Theodore M. 1995. Trust in Numbers : The Pursuit of Objectivity in Science and Public Life. Princeton, N.J.: Princeton University Press.

Prescod-Weinstein, Chanda. 2020. "Making Black Women Scientists under White Empiricism: The Racialization of Epistemology in Physics." Signs: Journal of Women in Culture and Society 45(2):421-47.

Privateer, Paul Michael. 2006. Inventing Intelligence: A Social History of Smart. 1 edition. Malden, MA: Wiley-Blackwell.

Probolus, Kimberly. 2018. “'Drawn from Alice in Wonderland': Expert and Public Debates over Merit, Race, and Testing in Massachusetts Police Officer Selection, 1967-1979." Journal of the History of the Behavioral Sciences 54(4):237-55.

Reyhner, Jon and Jeanne Eder. 2004. American Indian Education: A History. Norman, OK: University of Oklahoma Press.

Rivera, Lauren A. 2017. "When Two Bodies Are (Not) a Problem: Gender and Relationship Status Discrimination in Academic Hiring.” American Sociological Review 82(6):111138.

Rodríguez-Muñiz, Michael. 2015. "Intellectual Inheritances: Cultural Diagnostics and the State of Poverty Knowledge.” American Journal of Cultural Sociology 3(1):89-122.

Ross, Dorothy. 1991. Origins of American Social Science. Cambridge, UK: Cambridge University Press.

Seamster, Louise and Victor Ray. 2018. "Against Teleology in the Study of Race: Toward the Abolition of the Progress Paradigm.” Sociological Theory 36(4):315-42. 
Shaw, Matthew P. 2016. "Bans on Affirmative Action in States with a History of StateSponsored Discrimination." in School Integration Matters: Research-Based Strategies to Advance Equity, edited by E. Frankenberg, L. M. Garces, and M. Hopkins. Teachers College Press.

Skrentny, John David. 1996. The Ironies of Affirmative Action: Politics, Culture, and Justice in America. Chicago, IL: University of Chicago Press.

Slater, Robert Bruce. 1998. "The First Black Faculty Members at the Nation's Highest-Ranked Universities.” The Journal of Blacks in Higher Education (22):97-106.

Smith, Linda Tuhiwai, Eve Tuck, and K. Wayne Yang, eds. 2018. Indigenous and Decolonizing Studies in Education: Mapping the Long View. New York: Routledge.

Soares, Joseph A. 2007. The Power of Privilege: Yale and America's Elite Colleges. Palo Alto, CA: Stanford University Press.

Somers, Margaret. 1996. "Where Is Sociology after the Historic Turn? Knowledge Cultures, Narrativity, and Historical Epistemologies." Pp. 53-89 in The Historic Turn in the Human Sciences, edited by T. J. McDonald. Ann Arbor, MI: University of Michigan.

Stevens, Mitchell L. 2007. Creating a Class: College Admissions and the Education of Elites. Cambridge, MA: Harvard University Press.

Stulberg, Lisa M. and Anthony S. Chen. 2011. "A Long View on 'Diversity': A Century of American College Admissions Debates." Pp. 51-62 in Diversity in American Higher Education, edited by L. M. Stulberg and S. L. Weinberg. New York, NY: Routledge.

Stulberg, Lisa M. and Anthony S. Chen. 2014. "The Origins of Race-Conscious Affirmative Action in Undergraduate Admissions: A Comparative Analysis of Institutional Change in Higher Education." Sociology of Education 87(1):36-52.

Tachine, Amanda R., Nolan L. Cabrera, and Eliza Yellow Bird. 2017. "Home Away From Home: Native American Students' Sense of Belonging During Their First Year in College." The Journal of Higher Education 88(5):785-807.

Teddlie, Charles and John A. Freeman. 2002. "Twentieth-Century Desegregation in U.S. Higher Education: A Review of Five Distinct Historical Era." Pp. 77-102 in Racial Crisis in American Higher Education: Continuing Challenges for the Twenty-first Century, Revised Edition, edited by W. A. Smith, P. G. Altbach, and K. Lomotey. Albany, NY: State University of New York Press.

Thelin, John R. 2004. A History of American Higher Education. Baltimore: Johns Hopkins University Press.

Thorngate, Warren, Robyn M. Dawes, and Margaret Foddy. 2008. Judging Merit. 1 edition. New York: Psychology Press. 
Tsay, Angela, Michèle Lamont, Andrew Abbott, and Joshua Guetzkow. 2003. "From Character to Intellect: Changing Conceptions of Merit in the Social Sciences and Humanities, 1951-1971." Poetics 31(1):23-49.

Veysey, Laurence R. 1965. The Emergence of the American University. 3rd ed. Chicago, IL: University of Chicago Press.

Warikoo, Natasha. 2016. The Diversity Bargain: And Other Dilemmas of Race, Admissions, and Meritocracy at Elite Universities. Chicago, IL: University of Chicago Press.

Waterman, Stephanie J. 2019. "New Research Perspectives on Native American Students in Higher Education." Journal Committed to Social Change on Race and Ethnicity 5(1):6080 .

Wechsler, Harold S. 2014. The Qualified Student: A History of Selective College Admission in America. New York, NY: Routledge.

Wilder, Craig Steven. 2013. Ebony and Ivy: Race, Slavery, and the Troubled History of America's Universities. New York, NY: Bloomsbury Publishing.

Wolfe, Patrick. 2016. Traces of History: Elementary Structures of Race. New York, NY: Verso Books.

Yanni, Carla. 2019. Living on Campus: An Architectural History of the American Dormitory. Minneapolis, MN: University of Minnesota Press. 